\title{
鼓室，乳突洞の再建
}

一耳珠軟骨板の応用一

村田清高

\section{Reconstruction of the Middle Ear with Tragal Cartilage}

\author{
Kiyotaka Murata \\ (Kyoto Univ.)
}

Removal of the posterior canal wall and broadening of the tympanic annulus were carried out in hopes of attaining a complete elimination of inflammation and cholesteatoma.

The technique was designed so that an antrum cavity and tympanic annulus with a cartilage plate would result. This cartilage plate divided the large excentrated mastoid cavity into two parts, namely reconstructed antrum and residual cavity exposed to the external canal.

A well ventilated middle ear space can be rebuilt using this procedure.

$$
\text { は じめに }
$$

鼓室形成術の目的は, 炎症の除去と伝音系の再建である.しかし, 従来の術式では, 外耳道後壁 骨性鼓膜輪をできるだけ残すよう操作するため，病巣の清掃が不充分となり，耳真珠腫の場合は， 再発をみるととが，少なくない，例えば，Sheehy ${ }^{20)} は ，$ intact canal wall technique では，35\% 真珠腫を取り残すといい，Donald et $\mathrm{al}^{4)}$ は，Scutum と耳小骨を残すと，70\%が不成功に終ると 述べている. Cole ${ }^{3)}$ あた, 外耳道後壁を残すと, 真珠腫の再発をみると述べている. Smyth ${ }^{21)}$ は, combined approach を用い, 術中, 完全に真珠腫を除去しえたと思う場合でも, 上鼓室, 中 鼓室に，それぞれ11〜 12\%真珠腫の取り残しがあると報告している．そして，子供の場合には，乙 の傾向がつよく，20\%に達すると述べている．さらに，段階的鼓室形成術を行った症例を検討した

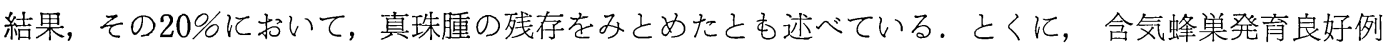
では, 術後 closed にする場合, 鼓室腔容積に対して, 乳突蜂巣削開により生じた腔の容積が大々 なる関係上，種々のトラブルがおこる ${ }^{17)}$ 。すなわち，ての場合には，小鼓室腔に対し，乳突蜂巣削 開後に生じた巨大腔がくっついた形になり，しかも，両者間をつなぐ狭い連結部には，耳小骨があ るので，ドレナージが不良となる．かくして，肉芽の増生が促進され，retraction cholesteatoma 出現の原因とあなる，以上のような事実を考慮すると，外耳道保存手術は，熟練者のみが行うべき あので(0)，一般耳科医のためには，他の術式が推賞さるべきと考える. 
そのう法の原則は, (1)外耳道後壁を除去し, 上鼓室を削開し, 骨性鼓膜輪屯広く拡大して, 徽底 的清掃を行えるよう手術を計画する。回次ぎに，良好な鼓室乳突洞を再建し，併せて，乳突蜂巣削 開後に生じた巨大腔の良好なドレナージを確保する様手術をすすめることであろう.

私は, この目的を達するため, 耳珠軟骨板を用い, 小乳突洞, 上鼓室を形成し, その一端を新生 鼓膜の支えに利用し，かつ，軟骨板より外側の残りの削開腔を外耳道へ開放するという方法を考案 した．乙れは，外耳道後壁の形成之，大きな鼓室腔の確保および開放腔に伴う種々の難点を軽減す るはずである. また, その術式から考えても, この方法は, 中耳根治術後の鼓室, 乳突洞の再建に あ応用できるはずである．本論文では，その手術手技とその理論的根拠について申し述べる.

\section{手 術手技}

この方法を正しく適用するには，症例を選ぶ 必要がある.すなわち, 外耳道後壁を除去し， 骨性鼓膜輪屯広く拡大して清掃を要する症例 が, この術式の適応といえる。例えば, 図 1 に 示した症例のように, 外耳道後壁がなく, 残り の骨性鼓膜輪を広く拡大した状態にあるむの が，その適応と考える。したがって，乙こでは このような症例を対象とした手技について述べ ることとする。

1.耳珠軟骨板を採取：耳珠の外側で, 外耳 道寄りに切開を行い（この切開を行う之，術後 の瘢痕がめだつととなく，美容的にみても望ま しい)，軟骨膜を両面につけた状態で，できる だけ大きく軟骨を採取する.

2. この板状の軟骨を, 図 1 の点線のごと く, トリミングする. この際，次の点に留意す る.すなおち, 中頭蓋䆚, 後頭蓋窩などと接着 する軟骨面 $\mathrm{a}-\mathrm{c}-\mathrm{b}$ の接着線は, 可能なかぎ り外側におき, 軟骨板の内側の腔(再建上鼓室, 乳突洞）を，できるだけ大きくするようつとめ ることである．次ぎに，鼓膜の支えに使用する $\mathrm{a}$ 一 $\mathrm{b}$ の部分は，もとあった外耳道後壁の鼓膜 輪にできるだけ近い位置とする。この操作によ り，鐙骨は，明視下におくことができる。なお， 軟骨板の固定がわるいときは, b 部分で, 楔状 の切れこみを入れ, 外耳道後壁の残りの高まり に，ての部が合致密着するようにすればよい. 以上のように操作すると，軟骨板の前の部分は 鼓膜の支えの一部として利用でき，後の部分は 乳突洞再建に役立つ。すなわち，乙の操作によ

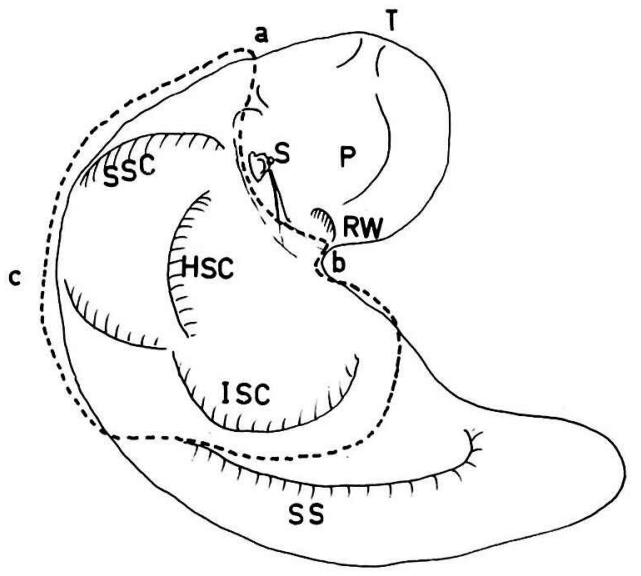

図 ।一右耳. 外耳道後壁を除去し, 骨性鼓膜輸を搪大 したところ.

T 耳管, P 岬角, RW正円空窩， S 鐙骨，S S C 上半規管, $\mathrm{H} \mathrm{S} \mathrm{C}$ 水平半規管, I S C 後半規管, S S S 状静脈洞骨壁.

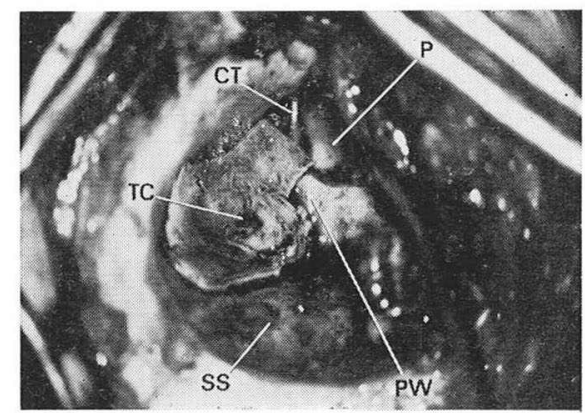

図 2 一右耳, 耳珠軟骨板で, 小乳突洞を形成したとこ ろ. T C 耳珠軟骨板, PW骨部外耳道後壁の残 りの高まり，C T鼓索神経，P岬角，S S S字 状静脈洞骨壁. 
り，外侧に残る削開によって生じた巨大腔を狭 小化することができる（図2）。

3. 鐙骨頭へ, コルメラを立て, 要すれば, スポンゼルで固定し（図 3 ), その外側へ，鼓 膜形成のため，側頭筋筋膜を張る。残余の筋膜 は，軟骨板のカバーにあてる（図4）。

4. 外耳道に, T切開を行うか, または, 简 状の上皮の長径に沿って, 2-3 ケ所切開し, 皮弁を形成し，新生鼓膜とした筋膜前部，上 部，下部をこの皮弁で被う。後壁の皮弁は，削 開腔を被覆するようにする。

5. 外耳道へ開放した削開腔が大きいとき は，側頭筋よりの前茎筋肉弁および，耳介後下 部の骨膜結合組織弁を作製し, 開放腔の上部, 後部および下部に充填し，腔を小さくし，かつ 露出骨面をできるだけ少なくする（図 5 ）。

6. この筋肉弁などの表面に, 外耳道後壁よ りの皮膚弁をあてる.

7. 外耳道より，スポンゼル，タンポンを入 机压迫する。

以上のような手技を行うと，図 6 に示したよ うな状態で, 鼓室乳突洞が再建される。また, 外耳道へ開放された削開腔は, 筋肉弁によって 充填され，著しく狭小化する.

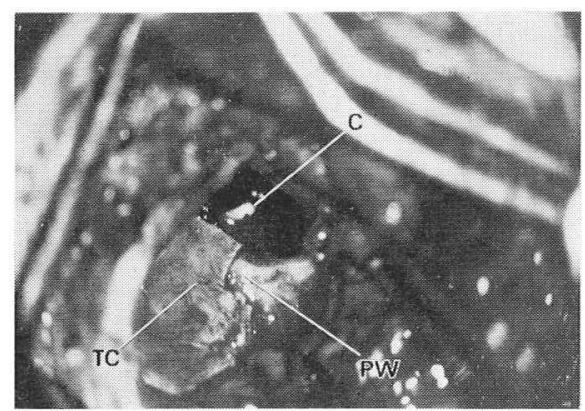

図 3一鐙骨頭に，コルメラを置いたところ．Cコルメ ラ.

中耳炎術後の鼓室乳突洞の aeration, ドレ ナージは, 2 通りの方法で行われる. その $1 つ$

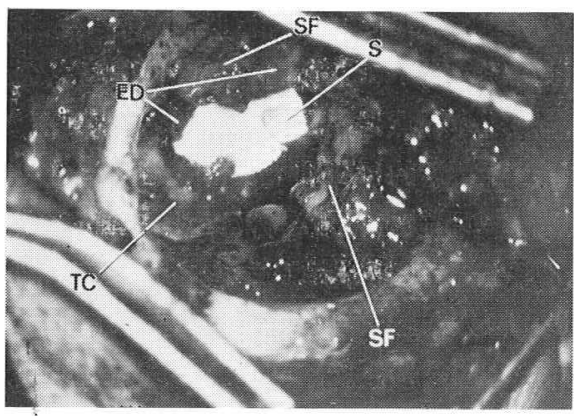

図 4 一筋膜で鼓膜を再建したところ，白い部分は, 鼓 膜上においたスポンゼル，E D 新生鼓膜，S ス ポンゼル，S F 外耳道皮膚弁。

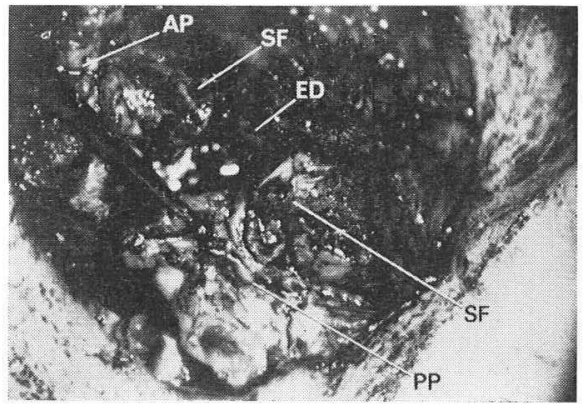

図 5一削開乳突洞へ，筋肉弁を充填する，鉗子でつま むのは後茎弁.

A P 前茎筋肉弁 P P 後茎骨膜結合織弁.

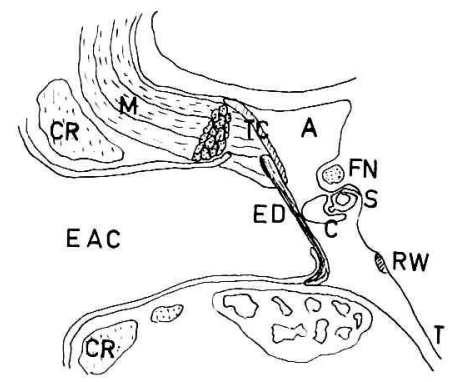

図 6一再建後の水平断面.

F N 顔面神経, RW正円空窩, S鐙骨, C コル メラ, $\mathrm{T}$ 耳管, $\mathrm{A}$ 再建乳突洞, $\mathrm{T} C$ 耳珠軟骨板 E D 新生鼓膜, E A C 外耳道, C R 耳介軟骨, M開放乳突腔虎充填する筋肉弁.

按

は，耳管を介して行われ，他は，削開腔を外耳 道へ開放するととにより行われる．前者は， 
Closed technique と呼ばれるものであり，後 者は, Cavity technique と呼ばれるあのであ る. 前者の利点は, 正常耳と同様の外耳道を維 持し，音響学的に有利であることである ${ }^{12)}$.し かし，乙の手技を行う場合は，上鼓室は狭く，か つ，耳小骨周囲のせまい隙間を介して，削開後 生じた巨大な腔よりの排泄が行われなけれげな らない。因みに，段階的鼓室形成術の成績が良 いのは, この部位に耳小骨がなく，ドレナージが 良好なととによると考えてよい。乙の問題の解 決は，削開によって生じた腔を外耳道へ開放す るととによってなされる (Cavity technique) が，乙の方法には，別の点で問題が生ずる.す なわち，術後の上皮化不良と音響学的損失であ る.

著者が，今回発表する手技に関連して，今一 度 Cavity technique と Closed technique の問題点を整理すると, 次の 3 つの問題にしぼ られる。

(1)狭い上鼓室を介して, 術後生じた巨大腔から のドレナージが行われる際の問題点 :

(1)この問題に関連して, 耳小骨連鎖の処置が 先ず検討さるべきと思う.

音響学的に考えると, 鼓膜より, 卵円空へ達す る伝音系路中にえられる音響利得は, 鼓膜, 鐙骨 板比を17，テコ作用を1.3とすると (Békésy ${ }^{1)}$ )， $27.5 \mathrm{~dB}$ である。 このうち，テコ作用による 利得は， $2.5 \mathrm{~dB}$ に過ぎない. このととは, 鼓膜と鐙骨が有効に連結されておれば，ほとん ぞ，中耳伝音機能に支障のないことを意味して いる. 臨床例で, 鼓膜が鐙骨に直接癒着し自然 に鼓室形成而型になったものや，段階的鼓室形 成術で，コルメラ形成後では，気骨導差のほ とんどない例をよく経験するが，乙れらのとと あ, 以上の結論を支持している，さて，手術を 行う場合, (1)耳小骨周囲の肉芽や真珠腫は, 耳 小骨連鎖を残存した状態で除去することは困難 である。(2)病巣除去の際，伝音系に与える機械

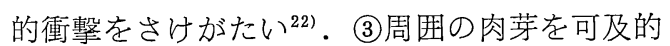
に除去する場合, 残存肉芽の増生で, 耳小骨周囲
は，狭险となり閉塞されやすい，以上の事実を 参照すると，手術にあたって，積極的に，砧鐙 関節をはずし，槌，砧骨を除去し，乙の部の清 掃を行ってのち，伝音系の再建をこころみる方 が，賢明といえる。私は，本手術法の適応にな るような症例では，積極的に耳小骨を除去し， その周囲の肉芽を除去し, 耳小骨再建の際には コルメラとして，砧骨を使用している。そして ，乙の方法を実施するととにより，再建耳小骨 連鎖の周囲の隙間は，数倍化されることを経験 している. retraction cholesteatoma の原因 を, scutum の除去の有無や, 外耳道後壁の補 填の有無と関連して考えるものも多いが，乙れ は, むしろ, 2 次的な要因であり,一次的要因之 しては，手術により生じた巨大削開腔と小鼓室 腔の間の狭隘な連結部の存在にあると考える. というのは, このような状況下では, Bernouilli の原理によって, 狭险部に, 常に陰圧が加わる はずであり ${ }^{21}$ ，この条件下では，耳小骨，とく に槌砧骨などの支えは，かえって，形成した鼓 膜の陥凹を促進することになると考えられる。 以上の理由からも, 私は, 耳小骨連鎖周囲に は, 可及的に大きな隙間をつくる必要があると 考えている. とくに炎症が強いものや, 真珠腫 の場合には, この配慮が必要で, 槌砧骨を残存 してよい根拠はない.なお，コルメラに使用す る耳小骨の運命については, 多数の検討があ り，他の手術手技による場合でも，同じととが 言えるので，ここでは省略する.

(口鼓室と乳突洞の狭险な連結部を拡大する方 法として, 中頭蓋筒直下部, 迷路上部などの Anterosuperior perilabyrinthine air cells の開放は有効な方法と考えてよい.

真珠腫, 増生肉芽を徹底的に除去するには, 上述の部位の病巣む除去するととが必要であ る。そして，てれを忠実に行うことによって， 鼓室と乳突洞間には，必然的に広い通路が形成 されることになる，また，乙の際，上鼓室の再 建を可能とする手技が考案されておれば，ての 部位を充分に除去して，清掃を行いうるので， 
以上の目的達成にさらに有利な条件を加えたて とになる。そして，上述したように，私の手術 方法では, 軟骨板の一端を鼓膜の支えに使用し ているので, この面からも，ての手技は利点を 有している.

削開によって生じた巨大腔を狭くする obliteration technique ${ }^{8)}$ は, 上述の狭险部 に与える巨大な削開腔の影響を少なくする目的 の手術之考元てもよい．しかし，乙の方法で用 いる充填物は, 骨片を除けば次の点で問題があ る。例えば側頭筋, 脂肪, 骨膜9, 結合組織な ぞを用いる場合には，それらから扔てる渗出液 や壊死組織などの発生を無視しうる訳にはいか ず，これまでの方法では，そのドレナージは， 前述の狭い通路を介して行わざるをえない，著 者の方法では, 以上の充填物を収める腔を外耳 道へドレナージしてあるので，ての問題は解決 されている。

(2)開放乳突洞の不良上皮化の問題：

乳突蜂巣削開に関連する問題点としては，5 つの点があげられる，すなわち，(1)病巣含気蜂 宩の残存, 回削開後化生ずる狭くかつ複雑な部 位での, 再生上皮眝留と感染, 骬膜を欠く粗

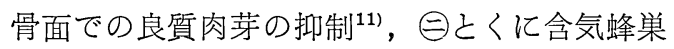
発育良好例では, 削開後に生ずる巨大腔と関連 するトラブル ${ }^{17)}$ ， 困この他に，外耳道に巨大腔 が随伴する際の音響学的不利122, なごがこれに 該当する.

さて, 以上の問題を考慮しながら, 私の行っ た手術方法の功罪を考えてみたい．

著者の方法では, 上述の(1)回の問題解決のた め, 次の工夫を行っている，すなわち，迷路周 囲および隅角の蜂巣の削開面を，軟骨板内側に おき，粘膜面として再建される乳突洞に含めて ある. 汃くして，上述の蜂巣削開之関連してお こる上皮化の問題を回避しうるととになる. 次

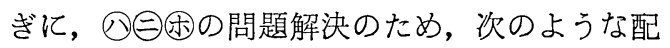
慮を行っている，すなわち，使用する軟骨板を できるだけ大きくし，外耳道へ開放する削開に よって生じた巨大腔の割合を少なくするよう努
カしている．乙の努力を行っても，なお開放腔 が大なる場合には，Musculoplasty の手技を 用い, 前茎弁後茎弁の両者を, 開放腔の後外側 に充填し，加つ，その表面を，外耳道より皮虔 弁で覆ってある．ての操作を行うことにより， 粗骨面の露出は少なくなり, 肉芽増生, 上皮化 は良好となる ${ }^{11)}$ 。また，開放腔は，小さくな る。

(3)巨大開放腔に伴う音響学的損失の問題： 上述の筋肉弁充填之, 軟骨板を可及的に外側に 位置させるととで改善される。

以上の術式の特徴を要約すると次のようにな る。すなわち，炎症抑制の面からみると，ての 方法では, 外耳道後壁の除去, 骨性鼓膜輪の拡 大を行うことになり，病巣を広範に除去清掃し うる。また，削開により生じた巨大腔は，2つ に分けられ，1つは，外耳道へドレナージし， 残りの再建小乳突洞之鼓室腔は, 耳管へドレナ ージすることになる.

次ぎに，伝音系の再建の面加ら，乙の手技の 特徵を述べると次のようになる。すなおち，軟 骨板で，鼓膜後部を支えるので，耳小骨連鎖の 再建や鼓膜再建は容易之なり，かつ，大きな鼓 室腔を確保できるととになる，さらに，開放县 を筋肉弁，軟骨板で狭くし，上皮化困難化を防

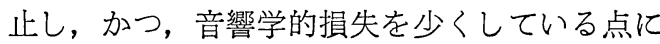
利点がある。

本法に関連して次の問題点について，私見を 述べておきたい。

(使用される軟骨板の運命については，長期 の follow-up を要するので，現段階では，決 定的なととは言えない。しかし，中耳へ留置し た軟骨については，比較的長期間残存したとの 報告がある ${ }^{15) 19923)}$ ．また，柳原 ${ }^{24)}$ 亿よると，軟 骨は, 組織液によって栄養され, 移植に際して 炎症反応が少なく，感染に対して抵抗力が強く ，生着性良好という。さて，使用した軟骨板が ある一定期間の経過後吸収される場合には，次 の状態があたらされると思う。すなわち，その 外側は，上皮と上皮下の瘢痕組織となり，その 
内側は，粘膜面となると推测される。そして， てのような状況になってあ，私が上述したての 術式の利点は，なお，のとされていると考えた い.

(口次に段階的鼓室形成術 ${ }^{516)}$ との関連につい て次の考えを敷衍しておきたい．段階的鼓室形 成術では, 外耳道後壁を残しておく必要がある。 したがって，この術式では，病巣を充分に清掃 できない症例に遭遇する可能性がある。また， この手術法を採用すると，2回に分けて手術を 行うことになり，著者が今回発表する手術手技 は，乙の問題点が解決をみている点でも，有意 義と思っている.

最後に，次の事実を併記しておきたい。すな
わち，本法の適応症例としては，先にも述べた ように, 外耳道後壁, 骨性鼓膜輪などの広い除 去, 上鼓室削開を要する真珠腫, 著しい肉芽増 生を伴う中耳炎症例があげられるが，その他に 次の $1 ， 2 ， 3$ の問題とも関連して, 有用性が ある。

(1)含気蜂巣発育良好例では，外耳道後壁（橋 部）を残し，乙れと軟骨板を用いて，削開腔の 一部を外耳道ヘドレンする方法が行える。

(2)顎関節骨折その他の顔面外傷で，外耳道の 破損があるとき，乳突蜂巣削開による腔を介し て新しく，外耳道を作製できる。

(3)中耳根治術後の鼓室乳突洞の再建が可能之 なる。

\section{ま と め}

外耳道後壁の除去，骨性鼓膜輪の拡大を要する症例に，耳珠軟骨板を使用し，鼓室乳突洞を再建 する新しい試みを述べた。

桧学教授の御校閲を深謝致します.

\section{参考文 献}

1) Békésy, G. von \& Rosenblith, W. A. : The mechanical properties of the ear. In Stevens, S. S. (Fd.): Handbook of experimental psychology. (Shambaugh's Surgery of the ear 1967より引用)

2 ) Bhide, A. : Etiology of the retraction pocket in the posterosuperior quadrant of the ear drum. Arch. otolaryngol. 103 : 707 711, 1977.

3) Cole, J. M. : Conservative tympanomastoidectomy. Laryngoscope $84: 783 \sim 792,1974$.

4) Donald, P., McCabe B. et al : Atticotomy, a neglected otosurgical technique. Ann. otol. $83: 652 \sim 662,1974$.

5）柳原尚明, 山本悦生, 他：段階的鼓室成形術の検 討. 耳鼻臨床 $69: 311 \sim 316,1976$.

6) Goodhill, V.: Tragal perichondrium and cartilage in tympanoplasty Arch. otolaryngol. $85: 480 \sim 491,1967$.
7 ) 後藤敏郎監修.耳鼻咽喉科学 1960.

8）本多芳男：慢性中耳炎之手術的療法一特に真珠腫 の対策について一真珠腫症例の術後の変貌. 第79 回日耳鼻総会宿題報告，モノグラフ.

9）熊沢忠躬，馬場昭夫，他：Tympanoplasty にお いての骨膜を茎とする骨移植 耳鼻臨床 60 ： 521 524, 1967.

10）小出靖, 他: 乳突削開後の外耳道形成一手術の注 意点一耳鼻臨床 62：28～34, 1969.

11）小出靖，他：Mastoid 削開と外耳道形成一若干の 考察と試み一。耳鼻臨床 6I：187〜194，1968.

12）内藤儶, 他：Meatotympanoplastik 一特に術後聴 力を中心として一. 耳喉 $37:$ 405〜411，1965.

13）中野雄一：慢性中耳炎の病態と手術的療法一特に 真珠腫の対策について一. 上鼓室真珠腫の臨床, 第79回日耳鼻総会, 宿題報告モノグラフ.

14) Parkins, R. : Tympanomastoid reconstruction : An operative procedure for anatomical and functional restoration of the radicalized ear. 
Laryngoscope $86: 416 \sim 430,1976$.

15) Pfaltz, C. R. et al : Substitution of the stapedial arch by free cartilage graft. Arch Otolaryngol $87: 47 \sim 51,1968$.

16) Rambo, J. H. T. : The use of paraffin to create a middle ear space in musculoplasty. Laryngoscope 7I: 612 619, 1961.

17）斎藤春雄，他：乳突蜂巣発育良好例の手術. 臨床 耳科 $5: 136 \sim 137,1978$.

18）鈴木㴟一, 他：根治手術中耳の鼓室乳突洞の再 建. 耳鼻臨床 69:1665 1671 .1976.

19) Shea, M. C. et al : Tragal cartilage as an ossicular substitute. Arch. Otolaryngol. 86 : 308 317, 1967.

20) Sheehy, J. L. : Plastic sheeting in tympanoplasty. Laryngoscope $83: 1144 \sim 1159,1973$.
21) Smyth, G. D. L. : Postoperative cholesteatoma in combined approach tympanoplasty. Fifteen year report on tympanoplasty part 1. J. Laryng. Otol. : $90: 597 \sim 621,1976$.

22) Smyth, G. D. L. : Sensorineural hearing loss in chronic ear surgery. Ann. Otol. $86: 3 \sim$ 8, 1977.

23）高原滋夫, 他：鼓膜, コルメラ形成材料に何を用 いるか, その利点. 耳鼻臨床 $65: 372 \sim 374$, 1972 .

24）柳原尚明, 他：鼓室成形再手術における耳珠軟骨 の利用. 臨床耳科 $5: 202 \sim 203,1978$.

原稿到着：昭和53年 9 月 2 日 別刷請求先：村田清高 焉606 京都市左京区聖護院川原町53 京都大学医学部耳鼻咽㬋科学教室 